\title{
Subantarctic Mode Water variability influenced by mesoscale eddies south of Tasmania
}

\author{
Laura Herraiz-Borreguero $^{1,2,3}$ and Stephen R. Rintoul ${ }^{1,4,5}$ \\ Received 3 October 2008; revised 24 August 2009; accepted 27 October 2009; published 1 April 2010.
}

[1] Subantarctic Mode Water (SAMW) is formed by deep mixing on the equatorward side of the Antarctic Circumpolar Current. The subduction and export of SAMW from the Southern Ocean play an important role in global heat, freshwater, carbon, and nutrient budgets. However, the formation process and variability of SAMW remain poorly understood, largely because of a lack of observations. To determine the temporal variability of SAMW in the Australian sector of the Southern Ocean, we used a 15 year time series of repeat expendable bathythermograph sections from 1993 to 2007, seven repeat conductivity-temperature-depth sections from 1991 to 2001, and sea surface height maps. The mean temperature of the SAMW lies between $8.5^{\circ} \mathrm{C}$ and $9.5^{\circ} \mathrm{C}$ (mean of $8.8^{\circ} \mathrm{C}$, standard deviation of $0.3^{\circ} \mathrm{C}$ ), and there is no evidence of a trend over the 18 year record. However, the temperature, salinity, and pycnostad strength of the SAMW can change abruptly from section to section. In addition, the SAMW pool on a single section often consists of two or more modes with distinct temperature, salinity, and vertical homogeneity characteristics but similar density. We show that the multiple types of mode water can be explained by the advection of anomalous water from eddies and meanders of the fronts bounding the Subantarctic Zone and by recirculation of SAMW of different ages. Our results suggest that infrequently repeated sections can potentially produce misleading results because of aliasing of high interannual variability.

Citation: Herraiz-Borreguero, L., and S. R. Rintoul (2010), Subantarctic Mode Water variability influenced by mesoscale eddies south of Tasmania, J. Geophys. Res., 115, C04004, doi:10.1029/2008JC005146.

\section{Introduction}

[2] Subantarctic Mode Water (SAMW) is a thick nearsurface layer which occurs in the Subantarctic Zone (SAZ), the region defined between the Subantarctic Front (SAF) and the Subtropical Front (STF). It is formed in the winter mixed layers, which reach to depths as great as $700 \mathrm{~m}$, and it is characterized by high oxygen concentration [McCartney, 1977]. While SAMW is observed in each of the oceanic basins around Antarctica, the temperature and salinity properties vary along the circumpolar path: the warmest SAMW $\left(15^{\circ} \mathrm{C}, 35.8\right.$ practical salinity unit (psu), $\left.26.5 \sigma_{\theta}\right)$, which is the same as the main Subtropical Mode Water discussed by Provost et al. [1999], is found where the SAF is farthest north in the western Atlantic; the coldest mode water $\left(4^{\circ} \mathrm{C}-5^{\circ} \mathrm{C}, 34.5 \mathrm{psu}, 27.1 \sigma_{\theta}\right)$ occurs just west of

\footnotetext{
${ }^{1}$ Centre for Australian Weather and Climate Research, Hobart, Tasmania, Australia.

${ }^{2}$ Institute of Antarctic and Southern Ocean Studies, University of Tasmania, Hobart, Tasmania, Australia.

${ }^{3}$ Center for Marine Science, University of Tasmania, Hobart, Tasmania, Australia.

${ }^{4}$ Antarctic Climate and Ecosystems Cooperative Research Centre, University of Tasmania, Hobart, Tasmania, Australia.

${ }^{5}$ Wealth from Oceans National Research Flagship, Hobart, Tasmania, Australia.

Copyright 2010 by the American Geophysical Union. 0148-0227/10/2008JC005146
}

Drake Passage [Hanawa and Talley, 2001]. The extent to which the changes in SAMW properties around the circumpolar belt reflect gradual modification of a single water mass as it advects downstream is not clear.

[3] The formation and export of SAMW from the Southern Ocean to the subtropical gyres as part of the overturning circulation are of high relevance for climate change studies. SAMW ventilates the subtropical thermocline and transports atmospheric gases like carbon dioxide into the ocean interior [Metzl et al., 1999; Sabine et al., 2004]. The export of nutrients in the SAMW supports ocean productivity at low latitudes [Sarmiento et al., 2004]. Furthermore, SAMW properties (e.g., low potential vorticity) serve as useful tracers because they are retained for great distances, keeping a record of surface conditions at the time of formation [Hanawa and Talley, 2001].

[4] Previous studies of SAMW have revealed mechanisms that may contribute to its variability. Air-sea fluxes of heat and freshwater in the SAZ were first suggested to drive changes in the SAMW properties by McCartney [1977, 1982]. However, it has been reported that air-sea fluxes alone are not enough to explain the variability of SAMW. Northward Ekman transport across the fronts also contributes to SAMW formation and hence, its variability [Speer et al., 2000; Sloyan and Rintoul, 2001; Rintoul and England, 2002]. Eddy heat diffusion was recently shown 


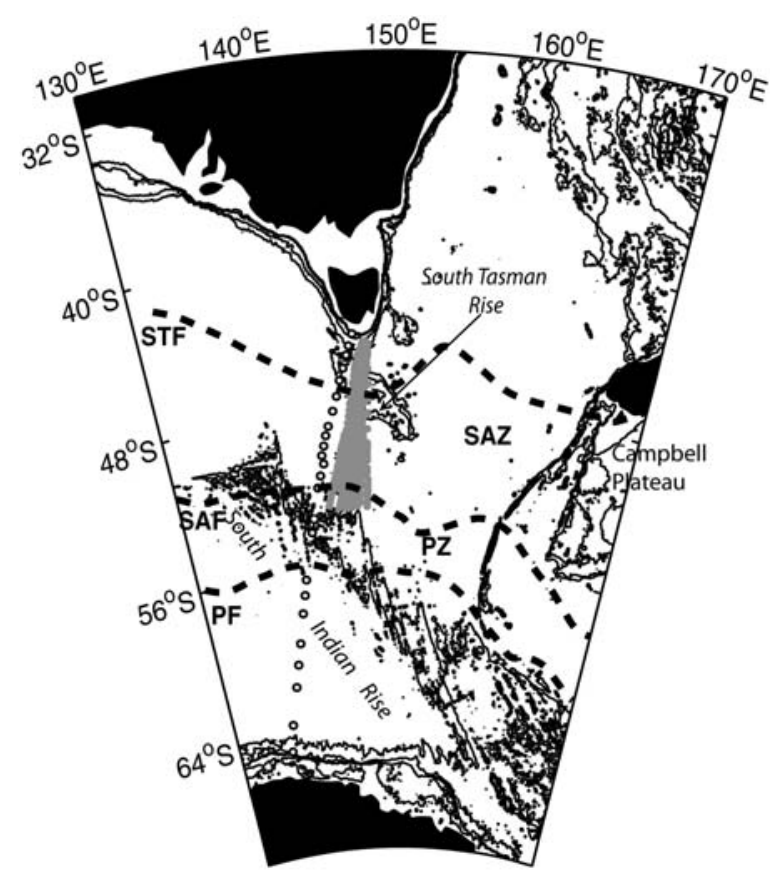

Figure 1. Location of hydrographic sections in the Subantarctic Zone (SAZ): WOCE SR3 CTD sections (open circles) and l'Astrolabe XBT sections (gray circles). Southern Ocean fronts south of Tasmania are indicated by dashed lines: STF, Subtropical Front (Southern Ocean Database); SAF, Subantarctic Front; PF, polar front, SAZ, Subantarctic Zone; PZ, polar frontal zone.

to modify the action of Ekman and air-sea fluxes, causing local heating/cooling of the SAMW [Sallée et al., 2008].

[5] Changes in the ocean heat and freshwater budget have been a topic of great interest in the last decade as a result of recent climate changes. Several studies have concluded that changes have occurred in recent decades. Southern Ocean temperatures in the depths between 700 and $1100 \mathrm{~m}$ have warmed approximately $0.17^{\circ} \mathrm{C} \pm 0.06^{\circ} \mathrm{C}$ between the $1950 \mathrm{~s}$ and the 1980s, with the highest rise found near the Antarctic Circumpolar Current (ACC) [Gille, 2002]. SAMW warming is consistent with subduction of warmer surface waters from south of the ACC [Wong et al., 2001; Aoki et al., 2003]. On density surfaces and in the formation areas, SAMW shows a freshening and warming in the Indian and Pacific sectors of the Southern Ocean between the 1960s and the 1990s [Bindoff and Church, 1992; Bindoff and McDougall, 2000; Johnson and Orsi, 1997; Wong et al., 1999; Bryden et al., 2003] and has been linked to anthropogenic carbon dioxide emissions [Banks et al., 2000]. However, the salinity in the Indian Ocean recovered to the 1960s values in 2002 [Bryden et al., 2003]. Some studies using oceanic models suggest the observed changes may reflect natural or internal variability rather than a long-term trend [Stark et al., 2006]. The Pacific and Atlantic sectors of the Southern Ocean also show freshening in the periods between the 1980s-1990s and 1950s-1960s [Curry et al., 2003; Wong et al., 2001]. However, earlier studies have relied on infrequent repeats of hydrographic sections, which may alias short-term variations in water properties. A recent work examining a time series of SAMW properties in the Drake Passage between
1969 and 2005 showed high variability on interannual to interdecadal time scales, with warming (by $\sim 0.3^{\circ} \mathrm{C}$ ) and an increase in salinity (by $\sim 0.04$ ) during the $1970 \mathrm{~s}$, and cooling and freshening trends between 1990 and 2005 [NaveiraGarabato et al., 2009]. The interdecadal variability in SAMW properties was primarily driven by trends in the major modes of Southern Hemisphere climate variability (the Interdecadal Pacific Oscillation, Southern Annular Mode (SAM), and the El Niño-Southern Oscillation). The lack of continuous time series of hydrographic measurements at key formation areas in the Southern Ocean and the poor understanding of the physical processes that imprint the temperature and salinity signal to the mode waters at the surface make it difficult to interpret changes observed in areas far from where SAMW subducts.

[6] In regions south of Australia, Subantarctic Mode Water forms a thick layer of uniform density (a pycnostad) from 26.8 to 26.95 , and thus, a layer of very low potential vorticity. The vertical extent can reach 450-700 dbar from the surface, and it can be found between $45^{\circ} \mathrm{S}$ (STF mean position) and $50^{\circ} \mathrm{S}-53^{\circ} \mathrm{S}$ (SAF mean position) [Sokolov and Rintoul, 2002]. No SAMW has been found farther north than $36^{\circ} \mathrm{S}$ in the Tasman Sea [Sokolov and Rintoul, 2000]. To the east the Campbell Plateau $\left(160^{\circ} \mathrm{E}-165^{\circ} \mathrm{E}\right)$ prevents the type of SAMW found at the World Ocean Circulation Experiment (WOCE) SR3 $\left(\sim 145^{\circ} \mathrm{E}\right)$ transect from entering the Pacific Basin [Rintoul and Bullister, 1999]. It is often assumed that there is a single mode or type of mode water at each location. We show how the SAMW south of Tasmania can be composed of different modes and discuss their origins.

[7] The intra-annual and interannual variability of SAMW has been examined south of Tasmania. Temperature and salinity properties of SAMW are described in section 3.1, followed by the SAMW core temperature time series. SAMW variability is described in more detail by considering several case studies in section 3.3, ending with a brief description of the seasonal evolution of the SAMW properties.

\section{Data Analysis}

[8] Conductivity-temperature-depth (CTD) recorder and expendable bathythermograph (XBT) data sets were used to determine the magnitude and cause of temporal variability of the Subantarctic Mode Water south of Tasmania. Seven repeat CTD transects from the WOCE SR3 sections were collected during voyages of the R/V Aurora Australis. Data were retrieved in several years: November 1991, March 1993, January 1994, January 1995, July 1995, September 1996, and November 2001, covering temporal sampling across most seasons. Stations along SR3 were generally about $55 \mathrm{~km}$ apart in the Subantarctic Zone. Useful information on WOCE SR3 sections is given by Rintoul and Bullister [1999], Sokolov and Rintoul [2002], and Rintoul et al. [2002].

[9] The second data set used comes from the joint XBT program between France, Australia, and the United States from the French vessel l'Astrolabe (Surveillance de l'Ocean Austral (SURVOSTRAL)) between Tasmania and the French Antarctic base Dumont D'Urville $\left(66^{\circ} \mathrm{E}, 140^{\circ} \mathrm{E}\right)$. XBT temperature profiles from repeat sections were taken 
a)

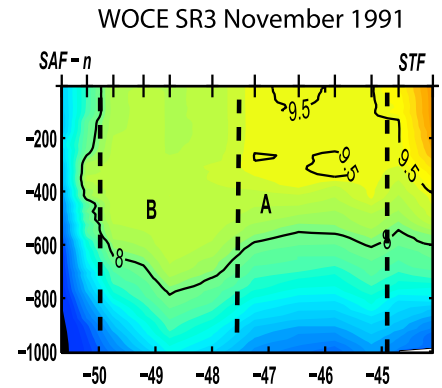

b)

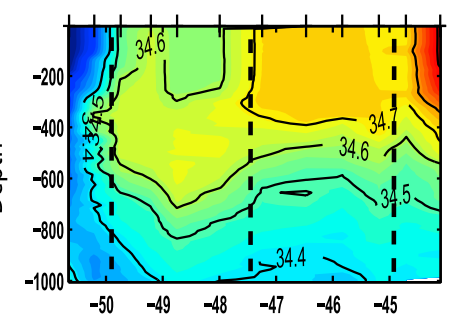

。

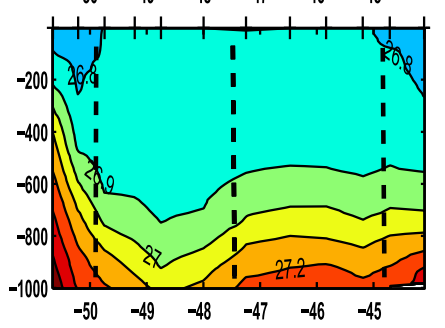

d)

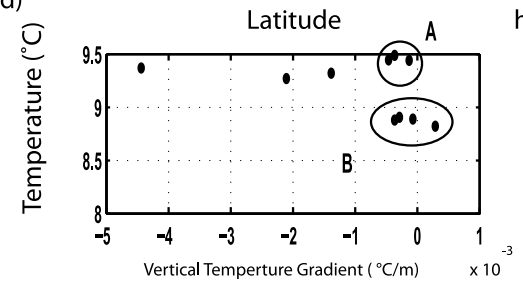

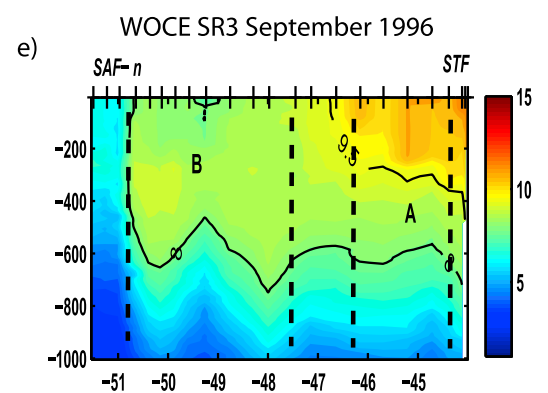

f)

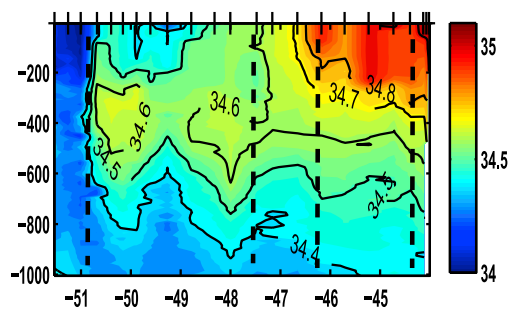

g)
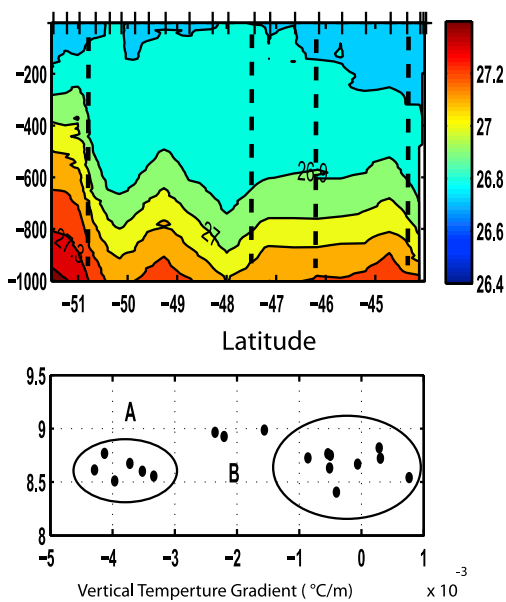

Figure 2. Vertical distribution of (a, e) temperature, (b, f) salinity, and (c, g) density for the hydrographic sections corresponding to WOCE SR3 November 1991 and September 1996, south of Tasmania. (d, h) SAMW (mean temperature per station versus mean $\mathrm{d} \theta / \mathrm{d} z$ per station) diagram. Each dot represents the mean temperature of the local SAMW at each station. Stations are depicted by small vertical lines at the top. Black dashed lines delimit regions of distinct SAMW characteristics (see section 3.3).

six times per year, when weather conditions made it possible, during austral summers between December 1993 and January 2007 . The homogeneity of mode water properties in the vertical allows us to use vertical temperature gradients from XBT profiles to identify the mode water core. Figure 1 shows the location of the CTD and XBT transects south of Tasmania and the mean position of the SAF and STF [Orsi et al., 1995]. The SURVOSTRAL XBT lines provide the longest available time series of temperature sections across the Southern Ocean. This time series allows the examination of the variability and the mechanisms driving variability of the SAMW. Faulty probes and poor weather caused gaps in some of the XBT sections. We restricted the analysis to sections where the distance between adjacent good profiles was less than $100 \mathrm{~km}$. A total of 44 out of 89 sections met this criterion.

[10] Sea surface height ( $\mathrm{SSH}$ ) maps provide insight into the processes responsible for SAMW formation and variability and allow our sections to be placed in a wider regional and temporal context. Satellite altimetry data have previously been used to study the mesoscale features and energetics of the ACC, in particular those associated with the SAZ [Hughes and Ash, 2001; Morrow et al., 2003; Sokolov and Rintoul, 2007]. For the SSH mean field (relative to 2500 dbar) we used Olbers et al.'s [1992] climatology, and for the anomaly we used the CLS/Archiving, Validation, and Interpretation of Satellite Oceanographic (AVISO) data "mean sea level anomaly" maps, which are produced by mapping data from the TOPEX/POSEIDON, ERS-1, and ERS-2 satellite altimeters [Le Traon et al., 1998]. We follow a sequence of SSH maps to identify the mesoscale features that cross our hydrographic sections south of Australia at the time of the sampling.

[11] SAMW is formed south of Tasmania between the Subtropical Front and the Subantarctic Front (Figure 1). Strong horizontal gradients in water mass properties are associated with fronts of the ACC [Orsi et al., 1995; Belkin and Gordon, 1996]; hence, isotherms can be used to identify the boundary of the SAMW region. The STF can be identified by the $11^{\circ} \mathrm{C}$ isotherm at $150 \mathrm{dbar}$, and the northern 


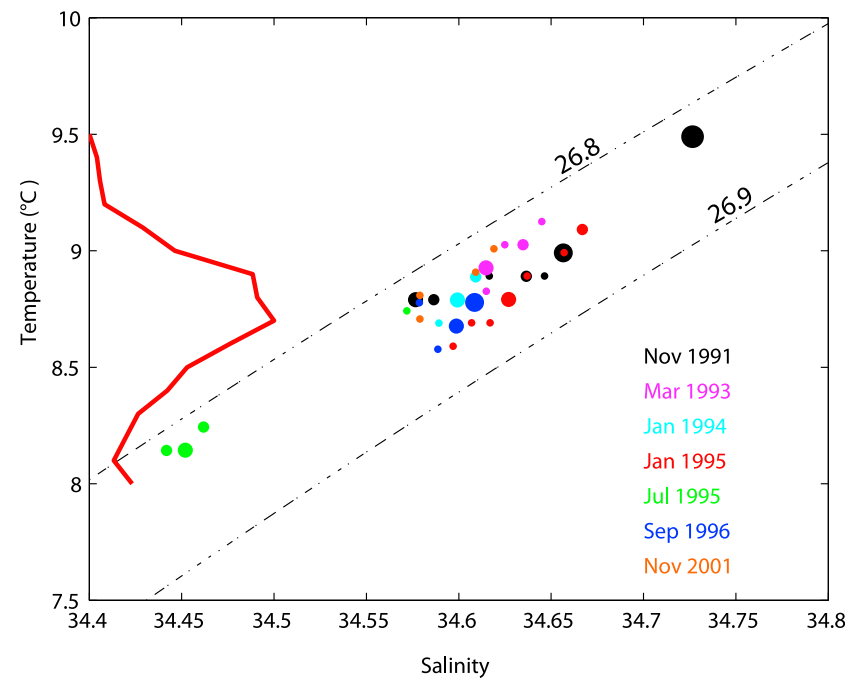

Figure 3. Variability of SAMW properties south of Australia [Rintoul and England, 2002, Figure 1] plus WOCE SR3 section November 2001). The cross-sectional area of water in each $0.1^{\circ} \mathrm{C}$ by 0.01 psu $\theta$ and $S$ class is shown by a filled circle, with the size of the circle proportional to the area. Only the large-volume $\left(>10^{7} \mathrm{~m}^{2}\right)$ modes are shown. Potential density contours are shown by black dot-dashed lines. A histogram showing the XBT temperature distribution of the local SAMW over the 15 years is seen on the left (thick red line). branch of the SAF can be identified by the $6^{\circ} \mathrm{C}-8^{\circ} \mathrm{C}$ isotherm at 400 dbar [Sokolov and Rintoul, 2002, Table 6].

[12] On the basis of the 18 years of XBT and CTD, we found that the local SAMW core around $140^{\circ} \mathrm{E}$ is well monitored by criteria based on temperature and vertical temperature gradient. A running mean average over $20 \mathrm{~m}$ was used to smooth the temperature profiles prior to the calculation of the vertical gradient over approximately $40 \mathrm{~m}$. We define the local variety of SAMW core as water with a temperature between $8^{\circ} \mathrm{C}$ and $9.5^{\circ} \mathrm{C}$ and a vertical gradient $|\Delta T / \Delta z|(\Delta z \approx 40 \mathrm{~m}) \leq 0.005^{\circ} \mathrm{C} \mathrm{m}^{-1}$. In order to compare $\mathrm{XBT}$ and CTD sections the same analysis has been applied to both. Therefore, the results are expressed mainly as a function of temperature and the vertical gradient of temperature.

\section{SAMW Variability}

\subsection{Temperature-Salinity Properties}

[13] Figure 2 shows an example of the vertical distribution of SAMW properties (potential temperature $(\theta)$ (Figures 2a and 2e), salinity $(S)$ (Figures $2 \mathrm{~b}$ and $2 \mathrm{f}$ ), potential density (Figures $2 \mathrm{c}$ and $2 \mathrm{~g}$ ), and $\theta$ versus $\Delta \theta / \Delta z$ (Figures $2 \mathrm{~d}$ and $2 \mathrm{~h}$ )) corresponding to two austral spring sections: WOCE SR3 November 1991(Figures 2a-2d) and September 1996 (Figures 2e-2h). The bottom of the pycnostad reaches to $600 \mathrm{dbar}$ in both sections. Density plots suggest there is a single pool with density between 26.8 and 26.9 , but temperature

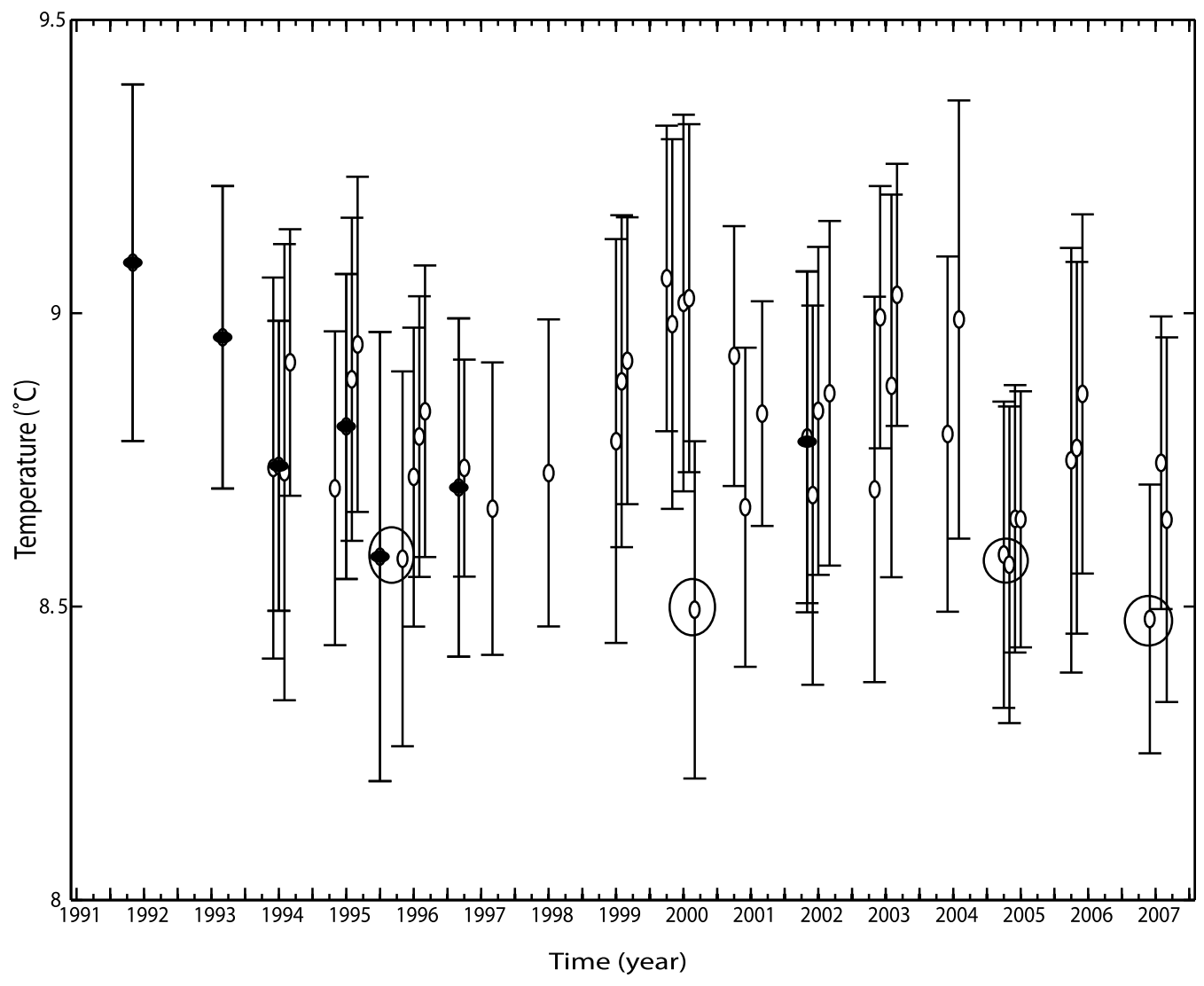

Figure 4. Monthly mean temperature of the SAMW core as a function of time. Black filled dots depict the WOCE SR3 hydrographic sections, and white filled dots depict the XBT sections. Error bars indicate the standard deviation of temperature per month (section). XBT data are available from October to March in each austral summer. Sections influenced by SAF eddies or meanders have been highlighted (ellipses). 

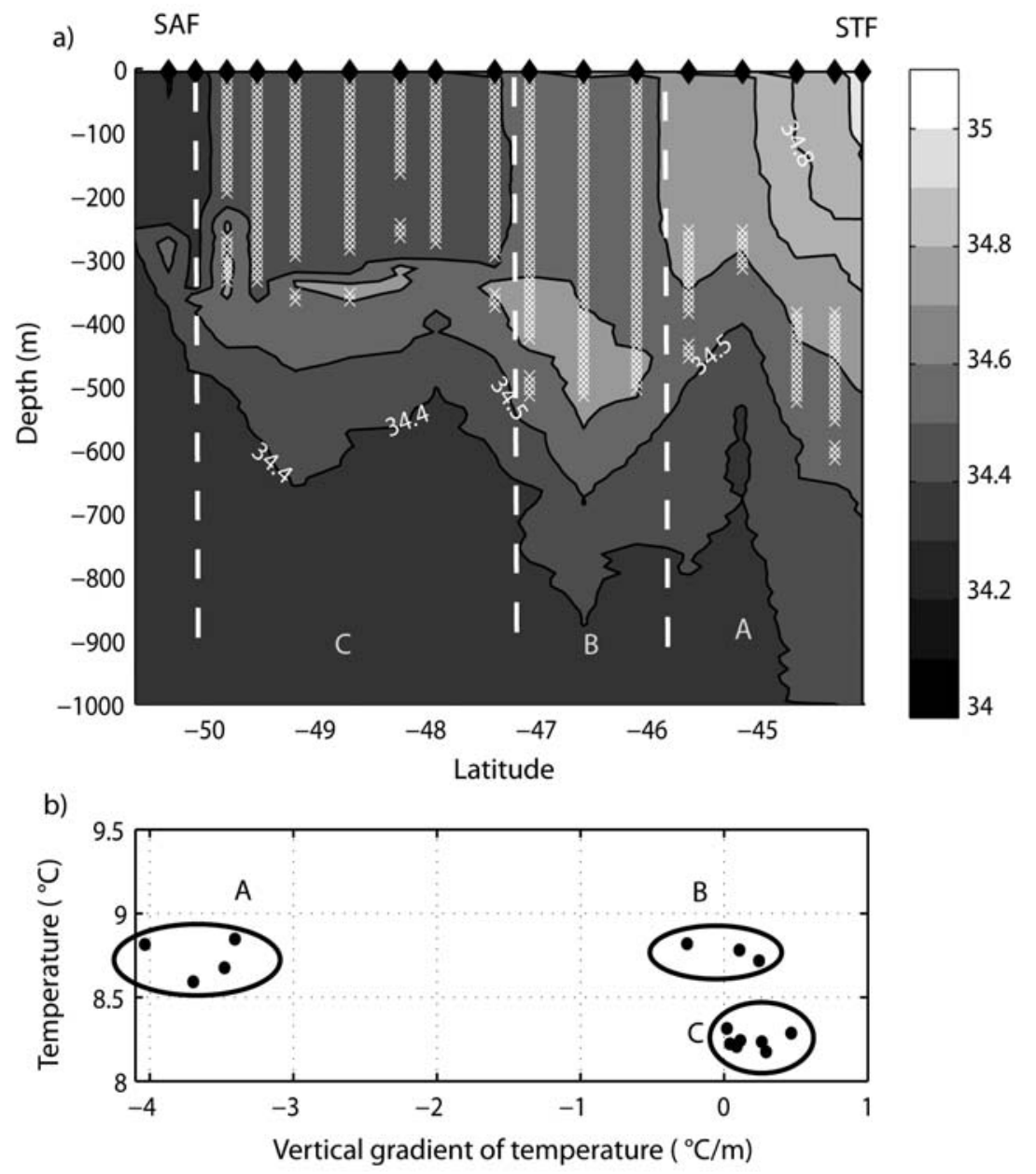

Figure 5. (a) Vertical distribution of salinity during the WOCE SR3 July 1995 . White crosses depict regions where the criteria used to define SAMW $\left(|\mathrm{d} \theta / \mathrm{d} z| \leq 0.005^{\circ} \mathrm{C} \mathrm{dbar}^{-1}\right.$ and $\left.\theta \epsilon[8,9.5]^{\circ} \mathrm{C}\right)$ are satisfied. Stations are shown by black diamonds at the top of the contour. (b) Classification of the water types that satisfy the SAMW criteria on the basis of the mean temperature and vertical temperature gradient.

and salinity sections suggest the SAMW pool is not completely homogeneous. This apparent heterogeneity in properties in the SAMW pool is clearer when $\theta$ is plotted against $\Delta \theta / \Delta z$ (same for salinity, not shown) (Figures $2 \mathrm{~d}$ and $2 \mathrm{~h}$ ). Each black dot (Figures $2 \mathrm{~d}$ and $2 \mathrm{~h}$ ) represents the mean temperature and mean $\Delta \theta / \Delta z$ for the local variety of SAMW at each station.

[14] The repeat WOCE SR3 CTD sections were used to evaluate the interannual variability of the SAMW properties south of Tasmania. Rintoul and England [2002] studied the variability of the SAMW properties using an area-weighted potential temperature-salinity $(\theta-S)$ plot. Here we have reproduced their Figure 1 with an additional section, SR3 November 2001 (Figure 3). We also added a histogram of the XBT temperature from the local variety of SAMW over the 15 year record. The majority of points fall in a cluster defined as $\theta \in[8.5-9]^{\circ} \mathrm{C}$ (coincident with the maximum XBT temperature frequency); $S \in$ [34.58-34.68] psu. There are two periods with strong modes which lie outside the central cluster. The XBT histogram highlights how uncommon these two modes are as they lie within the tails of the XBT temperature-frequency distribution. November 1991 shows a strong warm and salty mode $\left(\theta=9.5^{\circ} \mathrm{C}\right.$, $S=34.75$ psu); July 1995 shows a strong cold and fresh mode $\left(\theta=8.2^{\circ} \mathrm{C}, S=34.45 \mathrm{psu}\right)$ and a second weak mode close to the main cluster. A second minor peak in the XBT histogram is also found close to $8^{\circ} \mathrm{C}$.

\subsection{Core Temperature}

[15] An 18 year record of SAMW temperature from CTD and XBT data is used to study the interannual SAMW variability south of Tasmania. XBT data are available in each austral spring-summer from October to March. The observed monthly mean temperature of the local variety of SAMW core is depicted in Figure 4. The mean temperature plotted in Figure 4 is the monthly mean of all those observations satisfying the criteria for the local SAMW core: $T_{\text {SAMW }} \in[8-9.5]^{\circ} \mathrm{C}$ and $|\Delta T / \Delta z|_{\text {SAMW }} \leq 0.005^{\circ} \mathrm{C} \mathrm{m}^{-1}$. The mean temperature over the 18 years is $8.8^{\circ} \mathrm{C} \pm 0.3^{\circ} \mathrm{C}$, which is consistent with the main cluster observed on the hydrographic sections in section 3.1 (Figure 3). The error bars represent the standard deviation of temperature per month. 

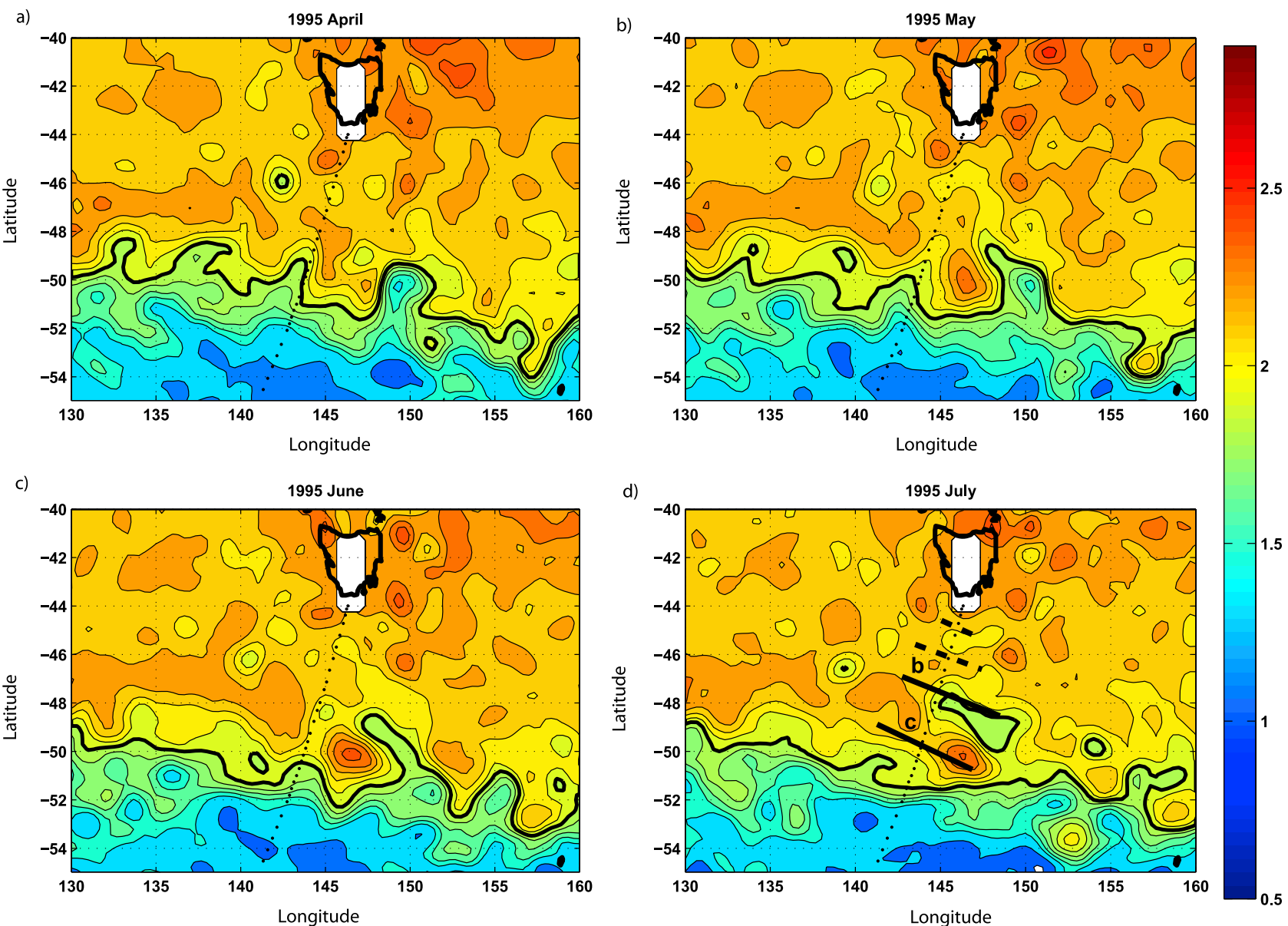

Figure 6. Sea surface height maps (m) south of Tasmania at the time of the WOCE SR3 section held on July 1995. Black bold lines correspond to the $1.9 \mathrm{~m}$ steric height as the position of the time-varying SAF (calculated as 0/2500 m mean steric height from Olbers et al.'s [1992] climatology plus the sea level anomalies from the TOPEX/POSEIDON plus ERS-1 and ERS-2 altimetry data defined by Sokolov and Rintoul [2002]).

While there are some abrupt jumps in temperature, e.g., summers of 1995-1996, 1999-2000, 2004-2005, and 20062007 , the variability is generally within the error bars, and there is no significant trend observed. These temperature changes are mainly cooling episodes. November 1991 is the warmest SAMW core in our time series, followed very closely by the beginning of summer in 1999. Air-sea fluxes or changes in the horizontal wind stress cannot explain entirely the variability observed in Figure 4 or the abrupt temperature changes as see in Figure 3. Different mechanisms have been claimed to drive SAMW variability: air-sea fluxes of heat and freshwater [Bindoff and Church, 1992; Johnson and Orsi, 1997; Wong et al., 1999; Banks and Bindoff, 2003], northward Ekman transport [Rintoul and England, 2002], and eddy heat diffusion modifying the action of Ekman and air-sea fluxes [Sallée et al., 2008]. An alternative hypothesis to describe the cause of the changes in the SAMW is the advection of anomalous water into the SAZ by eddies and meanders from the SAF. This is discussed in section 3.3.

\subsection{Multiple Modes}

[16] The vertical sections of $\theta$ and $S$ revealed heterogeneity of SAMW properties not seen in the vertical distri- bution of potential density (Figure 2). Moreover, the volumetric analysis of the $\theta-S$ properties in Figure 3 showed two sections, WOCE SR3 November 1991 and WOCE SR3 July 1995, with strong anomalous modes lying outside the main cluster. Similarly, we observed abrupt jumps in the SAMW core mean temperature during the summers of 1995-1996, 1999-2000, 2004-2005, and 2006-2007 from the analysis of the XBT sections (ellipses, Figure 4). In this section, we examine in more detail the SAMW heterogeneity found in Figures 2, 3, and 4 by considering a number of case studies.

\subsubsection{WOCE SR3 July 1995}

[17] Figure 5a shows the vertical salinity section corresponding to WOCE SR3 for July 1995. Within the SAMW pool observed on the section, we can easily distinguish the unusual cold-fresh mode in Figure 3 from the rest of the SAMW pool. Figure $5 \mathrm{~b}$ depicts the mean $\theta$ versus the mean $\mathrm{d} \theta / \mathrm{d} z$ of the local variety of SAMW at each station. The SAMW properties fall into three clusters. The temperature of modes $\mathrm{A}$ and $\mathrm{B}$ is consistent with the central cluster in Figure 3; the anomalously cool and fresh SAMW type (mode $\mathrm{C}$ ) is found in the southern SAZ, north of the SAF. Modes A and B have similar temperatures but 
a) WOCE SR3 Nov 1991

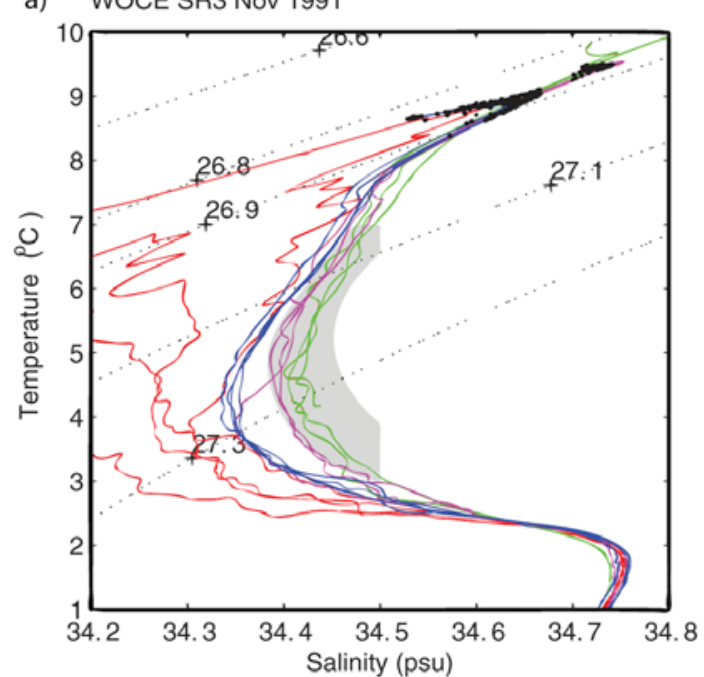

b) WOCE SR3 Jul 1995

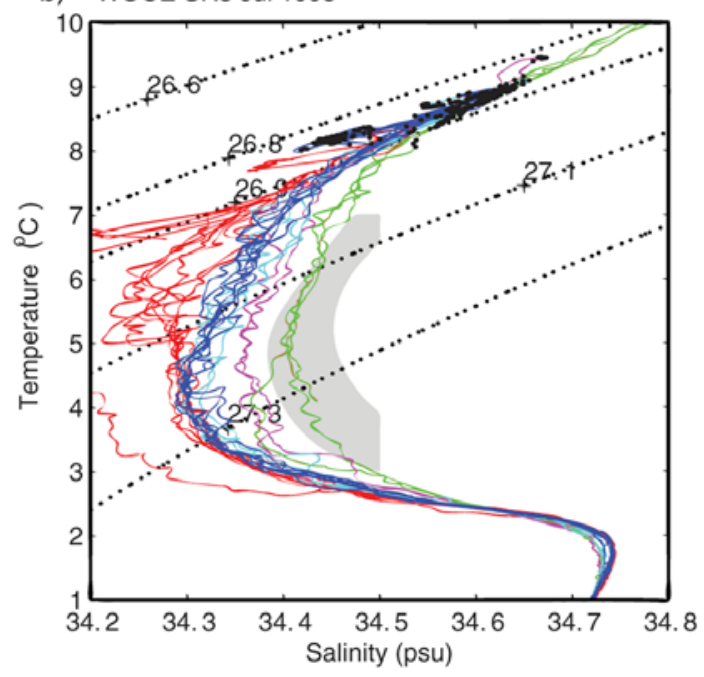

c)

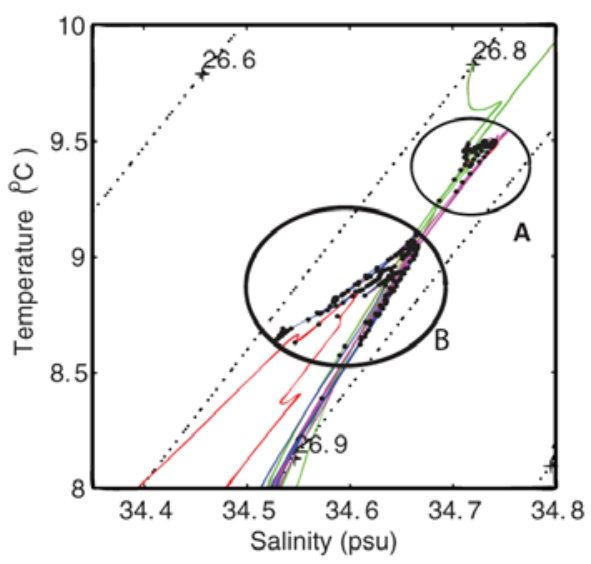

d)

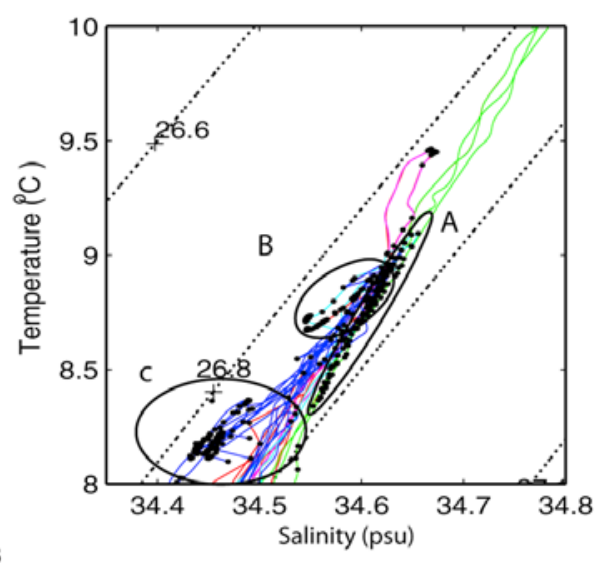

Figure 7. Potential temperature versus salinity relationship for (a, c) WOCE SR3 November 1991 and (b, d) WOCE SR3 July 1995. Black dots represent SAMW properties. Color code for WOCE SR3 November 1991 is green (stations northern STF), magenta (mode A), blue (type B), red (stations at/south of the SAF). Color code for WOCE SR3 July 1995 is green (just south of STF), cyan (mode A), blue (type B), red (stations at/south of the SAF).

different vertical temperature gradients. The larger vertical gradient in the subducted mode water north of $46^{\circ} \mathrm{S}$, labeled $\mathrm{A}$, indicates that mixing has eroded the pycnostad of this mode, which may have formed in the previous winter, while $\mathrm{B}$ has a well-developed thermostad and is located at $46^{\circ} \mathrm{S}-47.5^{\circ} \mathrm{S}$.

[18] What caused the particularly cold, fresh mode observed in July 1995 (mode C, Figure 5)? The monthly mean ocean heat loss in July 1995 over the SAZ along the SR3 line is about $137 \mathrm{~W} \mathrm{~m}^{-2}$ (data taken from the National Centers for Environmental Prediction (NCEP) reanalysis, $161 \mathrm{~W} \mathrm{~m}^{-2}$, from JPA-25 [Onogi et al., 2007]), and the evaporation minus precipitation flux is $0.003 \mathrm{~m} \mathrm{month} \mathrm{m}^{-1}$ (data taken from NCEP/National Center for Atmospheric Research (NCAR) reanalysis). To cool and freshen a $300 \mathrm{~m}$ thick by $1 \mathrm{~m}^{2}$ column by $0.5^{\circ} \mathrm{C}$ and $0.1 \mathrm{psu}$ (the difference between modes $\mathrm{B}$ and $\mathrm{C}$ ) requires a heat loss of about $238 \mathrm{~W} \mathrm{~m}^{-2}$ (using $\rho_{0}=1026.85 \mathrm{~kg} \mathrm{~m}^{-3}$, and $\mathrm{c}_{\mathrm{p}}=3986 \mathrm{~J} \mathrm{~kg}^{-1}$
$\mathrm{C}^{-1}$ ) and a freshwater input of about $0.9 \mathrm{~m}$ maintained for a month. This suggests that local air-sea forcing is insufficient to account for this change.

[19] TOPEX/POSEIDON SSH maps at the time of the section and for the previous 3 months are shown in Figure 6. In April, two cold-core meanders of the SAF are present at $143^{\circ} \mathrm{E}$ and $150^{\circ} \mathrm{E}$. The meanders grow in subsequent months and wrap around a warm (high $\mathrm{SSH}$ ) feature near $50^{\circ} \mathrm{S}, 146^{\circ} \mathrm{E}$. The cold, fresh mode $\mathrm{C}$ is observed where the July section crosses the low $\mathrm{SSH}$ features that originated as cold meanders of the SAF. Figures $7 \mathrm{~b}$ and $7 \mathrm{~d}$ show the $\theta-S$ relationship for WOCE SR3 July 1995. The SAMW potential density class is found between 26.8 and 26.9 (black dots). There is no density barrier between the SAF waters (in red) and mode $\mathrm{C}$ (in blue) which allows rapid cooling and freshening by mixing along isopycnals to occur in the SAMW where the cold meanders were seen. Note that the SAMW $\theta-S$ curves show a sharp "hook" toward cooler and 

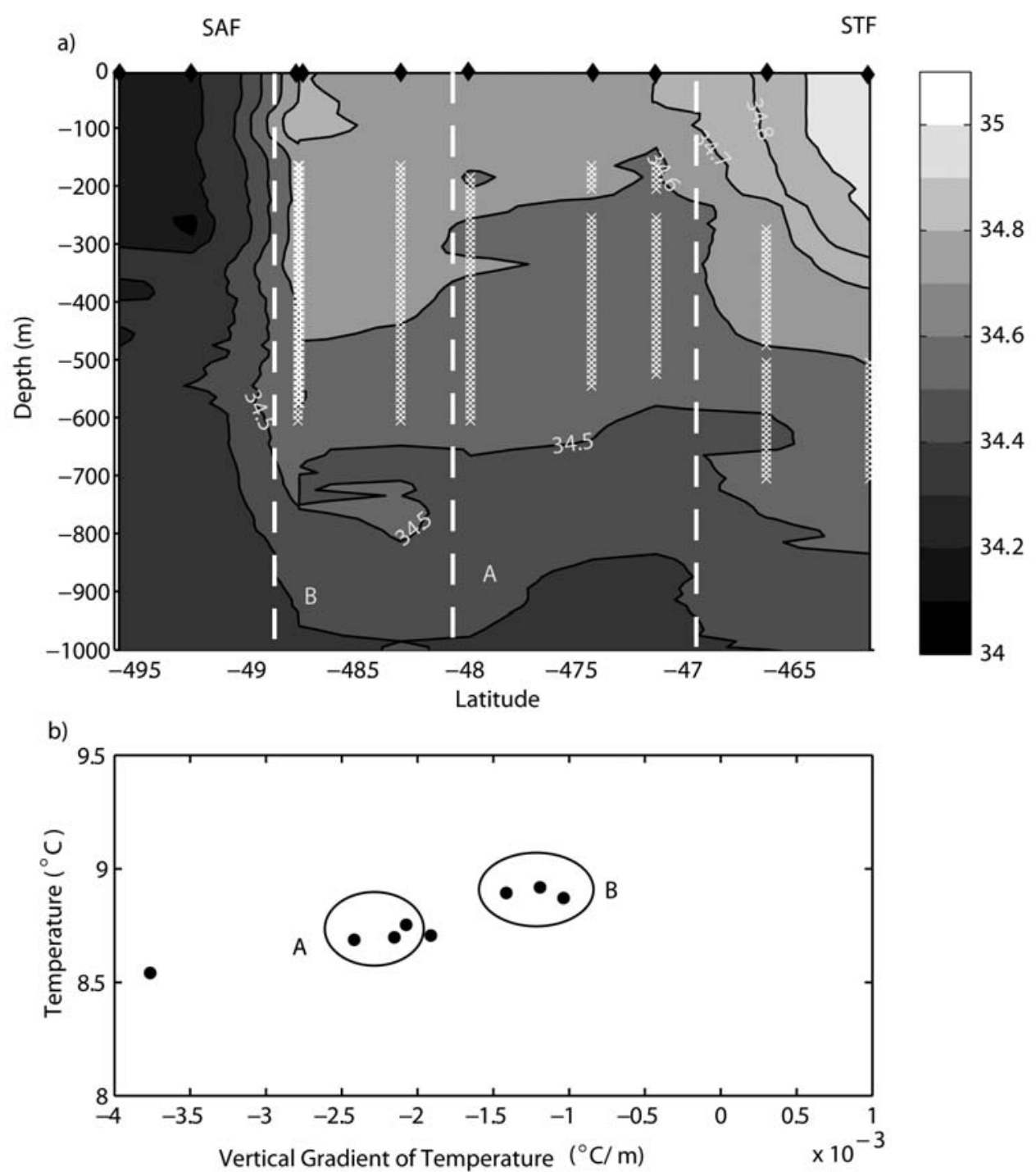

Figure 8. (a) SAMW vertical distribution of salinity during the WOCE SR3 November 2001. White crosses depict regions where the criteria used to define SAMW $\left(|\mathrm{d} \theta / \mathrm{d} z| \leq 0.005^{\circ} \mathrm{C} \mathrm{dbar}^{-1}\right.$ and $\theta \mathrm{c}$ $[8,9.5]^{\circ} \mathrm{C}$ ) are satisfied. Stations are shown by black diamonds at the top of the contour. (b) Classification of the water types that satisfy the SAMW criteria on the basis of the mean temperature and vertical temperature gradient.

fresher values near the sea surface, consistent with mixing with water to the south. The horizontal wind stress for July 1995 is not significantly different from the mean in this region. The proximity of the anomalous mode water to the SAF meander in the SSH map suggests that the advection of cold fresh water from the SAF by the meander, rather than northward Ekman transport, was responsible for the unusually cold, fresh mode water observed (Figures 3 and 5).

[20] We find a similar distribution of water properties on the WOCE SR3 transect in November 1991 (Figure 2a). Two distinct modes can be seen in the section: A $\left(45^{\circ} \mathrm{S}-\right.$ $47.5^{\circ} \mathrm{S}$; with $\left.9.4^{\circ} \mathrm{C}, 34.725 \mathrm{psu}\right)$ and $\mathrm{B}\left(47.5^{\circ} \mathrm{S}-50^{\circ} \mathrm{S}\right.$; with $8.3^{\circ} \mathrm{C}, 34.65 \mathrm{psu}$ ) (Figure 2) (note that we use the letters $\mathrm{A}$, $\mathrm{B}$, etc., to refer to distinct SAMW types observed on each individual section; there is no connection between mode A on different sections). Rintoul and Bullister [1999] showed that water masses can be influenced by subtropical water carried by the westward Tasman Outflow south of Tasmania (around $44^{\circ} \mathrm{S}$ ). The shaded areas in Figures $7 \mathrm{a}$ and $7 \mathrm{~b}$ represent the envelope of $\theta-S$ curves observed at $43^{\circ} \mathrm{S}$ in the Tasman Sea and show the $\theta-S$ range influenced by the Tasman Outflow from the repeats of the SR3 hydrographic section [see Rintoul and Bullister, 1999, Figure 6]. Profiles north of the STF (Figures 7a and 7c, in green) and of the SAMW mode A (Figures 7a and 7c, in magenta) are inside the shaded area, reflecting their subtropical influence. Sea surface temperature (SST) satellite images (not shown) show southward penetration of a warm temperature anomaly, likely the result of an eddy formed from the East Australian Current (EAC) extension. We used SST because no SSH maps exist that cover prior to 1992 . Similarly, monthly mean temperatures exceeded $9^{\circ} \mathrm{C}$ during the summer of 1999 (Figure 4). This relatively warm SAMW is associated with high $\mathrm{SSH}$ features moving southward following the East 
a)

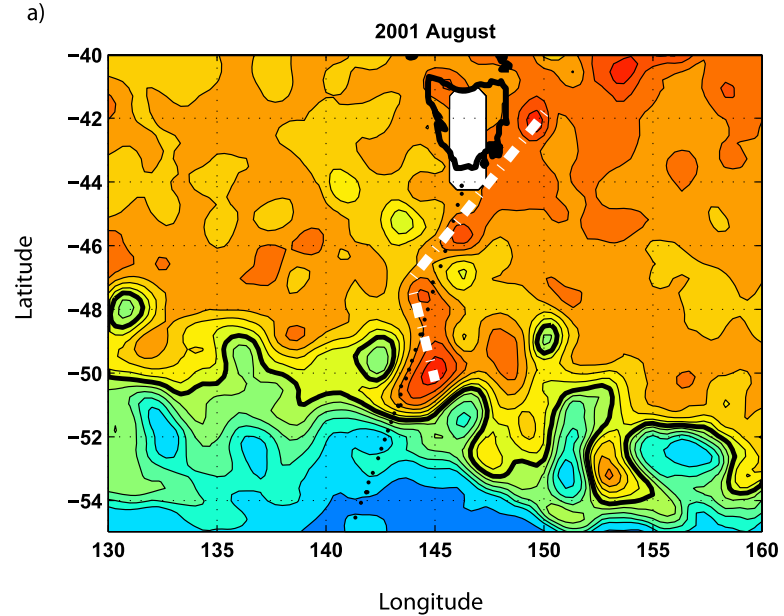

c)

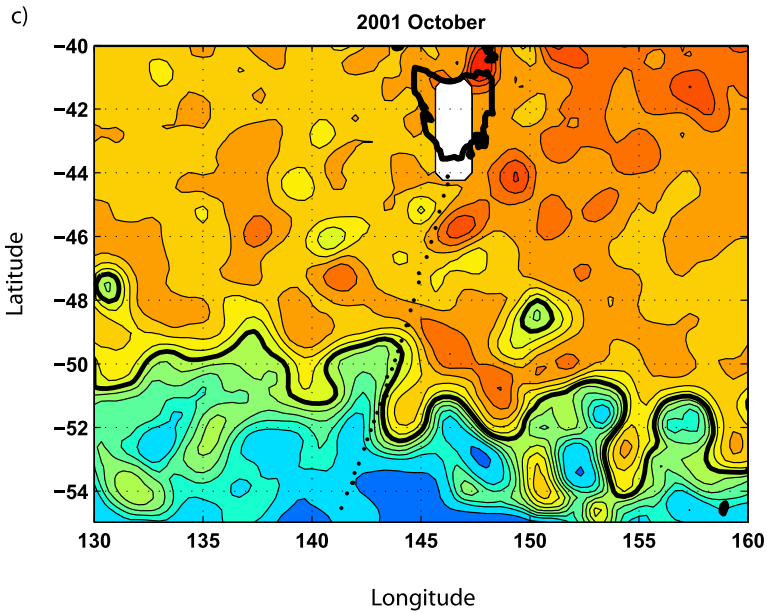

b)

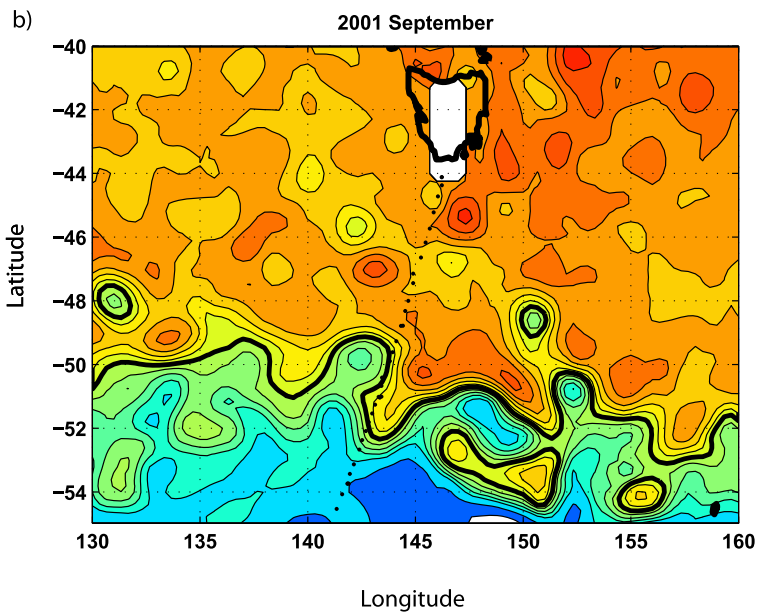

d)

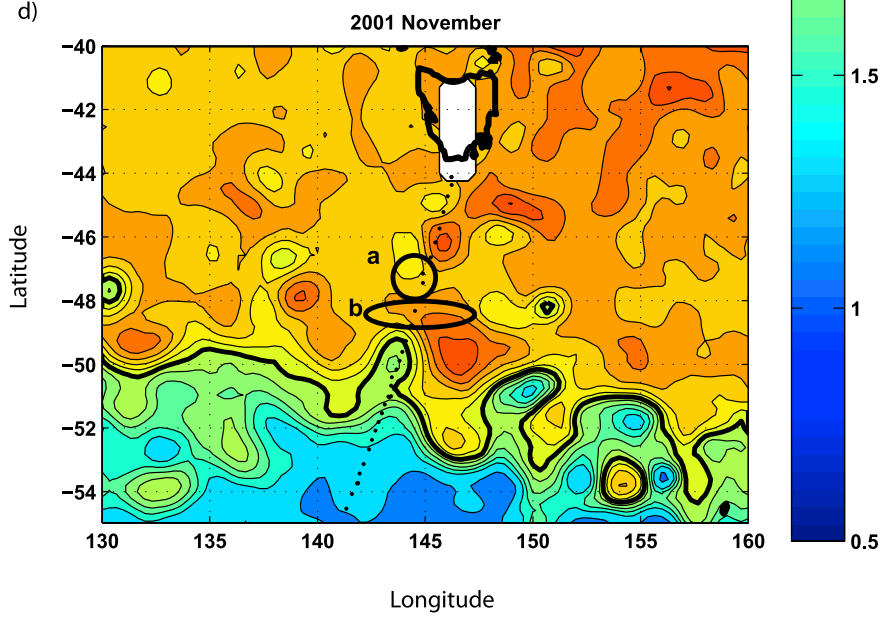

Figure 9. Sea surface height maps (m) south of Tasmania at the time of the WOCE SR3 section held in November 2001. Black bold lines correspond to the $1.9 \mathrm{~m}$ steric height as the position of the time-varying SAF (calculated as 0/2500 m mean steric height from Olbers et al.'s [1992] climatology plus the sea level anomalies from the TOPEX/POSEIDON plus ERS-1 and ERS-2 altimetry data defined by Sokolov and Rintoul [2002]).

Australian Current flow and advecting warm-salty waters into the SAZ. Warm and salty anomalies carried by the eddy and homogenized by deep winter mixing could explain the near $9.5^{\circ} \mathrm{C}$ core seen in Figure 3 .

\subsubsection{WOCE SR3 November 2001}

[21] Generally, SAMW temperature progressively cools and freshens from the STF to the SAF. However, in WOCE SR3 November 2001 the warmest-saltiest cluster (B) is situated closer to the SAF (Figures $8 \mathrm{a}$ and $8 \mathrm{~b}$ ). Although the difference between $\mathrm{A}\left(47^{\circ} \mathrm{S}-48^{\circ} \mathrm{S} ; 8.7^{\circ} \mathrm{C}, 34.57 \mathrm{psu}\right)$ and $\mathrm{B}$ $\left(48^{\circ} \mathrm{S}-49^{\circ} \mathrm{S} ; 8.9^{\circ} \mathrm{C}, 34.61 \mathrm{psu}\right)$ is not as extreme as in the previous examples, it is important to understand the origin of this reverse distribution of the horizontal temperature in the SAMW pool to improve our knowledge of the processes driving SAMW variability.

[22] We use the SSH maps from different months once again to describe the origin of clusters A and B (Figure 9). The CTD section crosses the eastern edge of a low dynamic height feature between $47^{\circ} \mathrm{S}$ and $48^{\circ} \mathrm{S}$ (Figure 9d), corresponding to cluster A in Figure 8. During August a path of high dynamic height can be seen from $42^{\circ} \mathrm{S}$ to $50^{\circ} \mathrm{S}$ (Figure 9a, white line). The path splits into three eddies in
August. The first eddy $\left(45^{\circ} \mathrm{S}, 147^{\circ} \mathrm{E}\right)$ moves slowly westward and is crossed by the November section at $46^{\circ} \mathrm{S}$. The second eddy $\left(47.5^{\circ} \mathrm{S}, 144.5^{\circ} \mathrm{E}\right)$ moves more rapidly to the west. The third feature appears to interact with the meandering SAF. In September it is located at $50^{\circ} \mathrm{S}, 144^{\circ} \mathrm{E}-149^{\circ} \mathrm{E}$ (Figure 9b). It is surrounded by SAF waters to the south and to the east by a SAF eddy. The core of the eddy seems to be stronger during October, maintaining part of its initial subtropical properties which imprinted the characteristics of cluster B water mass (Figure 9c). A warm temperature anomaly in the SST satellite images (not shown) supports the conclusion that the properties of $\mathrm{B}$ are influenced by advection of subtropical waters by eddies. Note that the eddies remain in the SAZ for several months during the winter, where they will be exposed to cooling by the atmosphere and deepening of the surface mixed layer, producing a volumetric mode. Morrow et al. [2008] showed how the November 2001 SR3 section showed strong mesoscale eddy structures. They also noticed a subsurface warming. They suggested the warming was forced by a poleward shift of the STF associated with a stronger Tasman Outflow. Following the time history of SSH, we arrive at a slightly different conclusion. The warm 

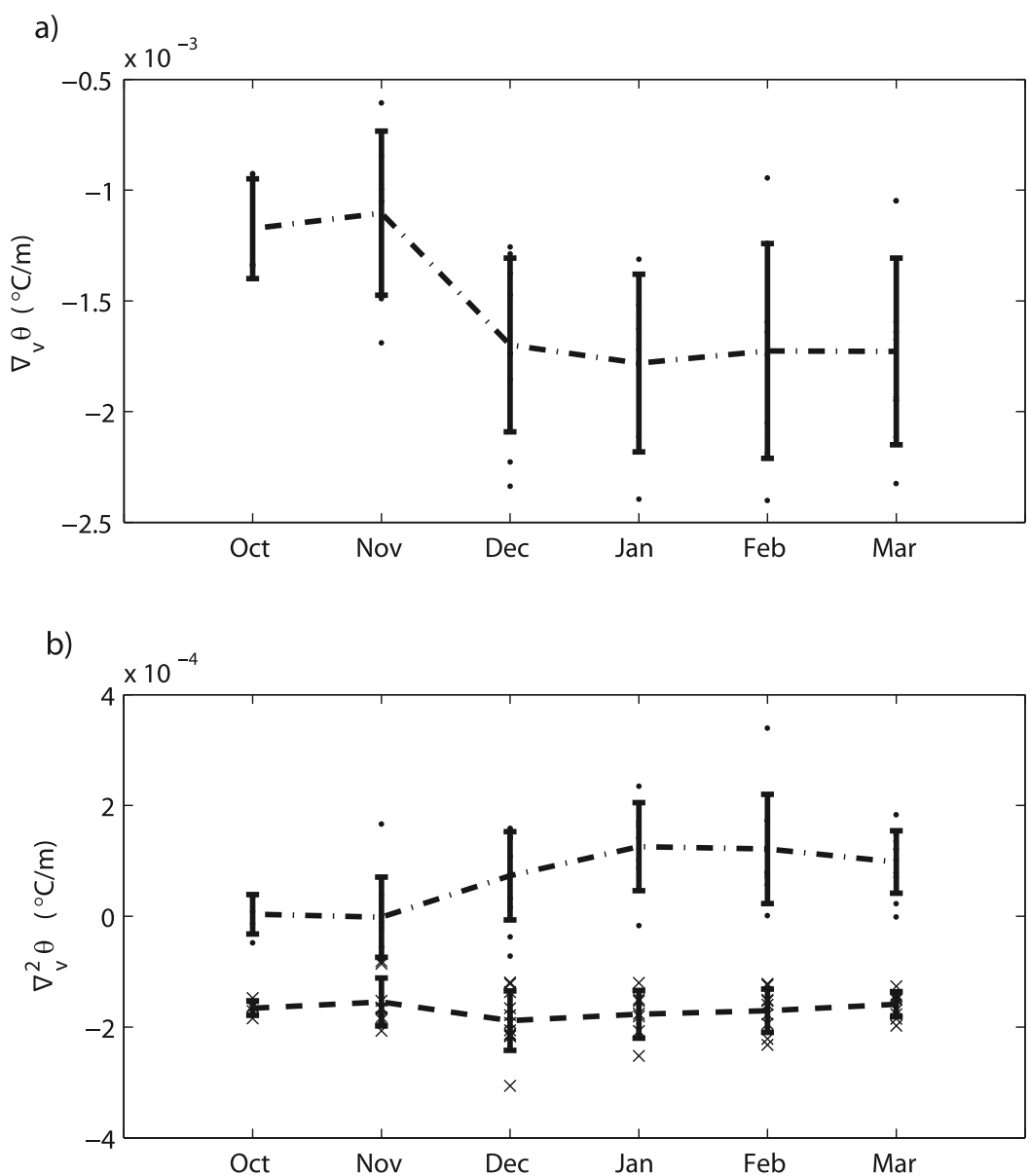

Figure 10. SAMW intra-annual variability. (a) Seasonal evolution of the SAMW core homogeneity. (b) Seasonal evolution of the erosion of the thermostad for the top (dash-dotted line) and bottom (dashed line) of the SAMW pool.

anomaly coincides with an eddy formed from the ridge of high SSH extending south from the subtropics rather than a stronger Tasman Outflow. We showed a strong warm-core eddy $\left(46^{\circ} \mathrm{S}, 145^{\circ} \mathrm{E}\right)$ located at the $\mathrm{STF}$ position given by Morrow et al. [2008]. By tracking eddies back in time we explained how the advection of anomalous water by eddies or meanders, rather than a stronger Tasman Outflow, influenced the SAMW properties.

\subsection{Seasonality}

[23] The seasonal evolution of the homogeneity of the SAMW core was studied using the distribution of the first derivative of temperature with respect to depth from the XBT sections. The SURVOSTRAL program only occurs during the austral spring-summer that are from October to March because of ice conditions. The homogeneity of the core of the SAMW is reflected in Figure 10a: the smaller the gradient, the stronger the thermostad. Qiu et al. [2006] showed the erosion of the North Pacific Subtropical Mode Water thermostad by evaluating the vertical gradient of potential vorticity at the edges of the Subtropical Mode Water. Here we show the erosion of the thermostad, at the top and bottom of the SAMW pool, by the second derivative of temperature with respect to depth (Figure 10b). The size of the error bars reflects the high intra-annual variability in the mode water. During October to November the gradient is small (Figure 10a), and SAMW is found from the surface to depths as great as $700 \mathrm{~m}$. The summer mixed layer generally starts to form in mid-November as the seasonal thermocline develops. Consequently, some of the SAMW formed that winter is capped by the summer mixed layer, and some is advected away from the formation area. We can see this interaction in Figure 10a, where mode water $\mathrm{d} T / \mathrm{d} z$ increases with the formation of the seasonal thermocline. The most pronounced $\mathrm{d} T / \mathrm{d} z$ increment occurs from November to December at the same time as the top of the SAMW core erodes (Figure 10b). The strength of the SAMW core remains constant from January to March. These results suggest that erosion of the SAMW core occurs mainly at the top of the SAMW pool, where it interacts with the seasonal mixed layer, with little further erosion of the thermostad during the summer.

\section{Summary and Discussion}

[24] The variability of SAMW south of Tasmania has been evaluated. We find evidence for significant year-toyear (and in some cases month-to-month) variability of SAMW properties but no trend over the 18 year period of observations. SAMW physical and biogeochemical 
properties at Drake Passage also showed substantial intraannual and interannual variability over the last four decades [Naveira-Garabato et al., 2009]. The large variability found south of Tasmania suggests caution is required when interpreting changes in SAMW properties from infrequently sampled sections. A clear mechanistic understanding of the source of SAMW variability is needed in order to interpret changes observed from sparse observations. In this study, we have focused on the contribution of mesoscale eddies to the variability of SAMW.

[25] We have shown that rapid and large shifts in SAMW properties can be explained by the advection of anomalous water by mesoscale features. It is often assumed there is a single mode or type of mode water at each location. Figure 3 showed strong "modes" with different temperature-salinity characteristics in SAMW. Sea surface height maps and water mass properties suggest these "modes" can be explained by the advection of anomalous water by mesoscale features into the SAZ, modifying SAMW properties in the formation area (sampling bias). Once the eddies have entered the SAZ, they can influence SAMW properties through isopycnal mixing. In addition, deep winter mixing will tend to mix the anomalous water vertically.

[26] It is likely that cold-fresh modes occur frequently because of eddies spawned from the ACC. The Australian sector of the Southern Ocean is a region with a high eddy kinetic energy [Phillips and Rintoul, 2000]. Baroclinic and barotropic instabilities of the SAF result in the formation of eddies and meanders. Eddy activity is enhanced in this region as a result of the interaction of the flow with the Southeast Indian Ridge as an attempt of the circulation to conserve its potential vorticity [Wolff et al., 1991; Morrow et al., 2004]. The frequent formation of cold-core eddies or meanders from the SAF explains why cold anomalies of SAMW are more frequent than warm anomalies in this region.

[27] Nevertheless, warm SAMW anomalies are occasionally observed. The SSH maps suggest these events can be linked to the input of warm and salty subtropical water by eddies of the East Australian Current. The EAC also regularly spawns eddies, and occasionally, these warm-core features extend as far south as the SAZ and influence the properties of the SAMW. Ridgway [2007a] showed that the EAC extends farther south in summer, and so the input of subtropical water to the SAZ is more common during the summer season. During the following winter, air-sea interaction drives deep convection and removes some but not all of the anomalous properties in the remnant eddy, resulting in a relatively warm and salty variety of SAMW.

[28] A key link in the Southern Ocean overturning is the conversion of deep water upwelling at high latitudes to less dense SAMW and Antarctic Intermediate Water (AAIW). The SAMW and AAIW are relatively fresh, and their export to lower latitudes closes the hydrological cycle by returning the excess precipitation falling at high latitudes. The formation and export of SAMW and AAIW also carry anthropogenic carbon dioxide into the interior and return nutrients from the deep ocean to the upper ocean to support biological productivity. The contribution of SAMW and AAIW to the overturning circulation, carbon storage, nutrient transport, and the hydrological cycle makes SAMW and AAIW critical components of the Earth's climate sys- tem. A change in the formation rate of SAMW would alter the capacity of the Southern Ocean to store heat and carbon, to export nutrients, and to influence the rate of climate change. Therefore, it is important to understand what drives variability in SAMW properties in the present climate and how SAMW formation and export will be affected by climate change.

[29] The Southern Annular Mode is the primary mode of atmospheric variability in the Southern Hemisphere. A positive trend in the SAM toward higher index state has been observed over the past 3 decades [Thompson and Solomon, 2002] and is projected to continue in the future as a result of increasing greenhouse gas concentrations in the atmosphere [Cai et al., 2003]. A higher positive Southern Annular Mode implies a strengthening in circumpolar wind stress over the Southern Ocean, with two important consequences. First, changes in wind stress can induce changes in the intensity of the Southern Ocean eddy field [Meredith and Hogg, 2006]. Second, changes in the Southern Hemisphere winds are also related to the intensification of the EAC southward penetration [Cai et al., 2005; Ridgway, 2007b]. As a result, the influence of mesoscale features over SAMW properties south of Tasmania is expected to increase.

[30] Our results suggest that assessing SAMW variability from infrequently repeated sections may produce misleading results by aliasing large interannual variability. Mesoscale circulation plays an important role in the interannual SAMW variability south of Australia, and it is expected to increase in a global warming scenario. As the fronts bounding the SAZ are hot spots for eddy kinetic energy along much of their circumpolar paths, we believe that mesoscale features will likely influence the properties of the SAMW at other locations in the Southern Ocean.

[31] Acknowledgments. This work is supported by the Australian Government Department of Climate Change through the Australian Climate Change Science Program and by the Cooperative Research Centre program of the Australian government through the Antarctic Climate and Ecosystems Cooperative Research Centre. The research is a contribution to the CSIRO Wealth from Oceans National Research Flagship. L.H.B. is supported by a joint Commonwealth Scientific and Industrial Research Organisation (CSIRO)-University of Tasmania Ph.D. scholarship in Quantitative Marine Science.

\section{References}

Aoki, S., M. Yoritaka, and A. Masuyama (2003), Multidecadal warming of subsurface temperature in the Indian sector of the Southern Ocean, J. Geophys. Res., 108(C4), 8081, doi:10.1029/2000JC000307.

Banks, H. T., and N. L. Bindoff (2003), Comparison of observed temperature and salinity changes in the Indo-Pacific with results from the coupled climate model HadCM3: processes and mechanisms, J. Clim., 16, 156-166, doi:10.1175/1520-0442(2003)016<0156:COOTAS $>2.0 . C O ; 2$.

Banks, H. T., R. A. Wood, J. M. Gregory, T. C. Johns, and G. S. Jones (2000), Are observed decadal changes in intermediate water masses a signature of anthropogenic climate change?, Geophys. Res. Lett., 27, 2961-2964, doi:10.1029/2000GL011601

Belkin, I. M., and A. L. Gordon (1996), Southern Ocean fronts from the Greenwich meridian to Tasmania, J. Geophys. Res., 101(C2), 3675-3696, doi:10.1029/95JC02750.

Bindoff, N. L., and J. A. Church (1992), Warming of the water column in the southwest Pacific Ocean, Nature, 357, 59-62, doi:10.1038/357059a0.

Bindoff, N. L., and T. J. McDougall (2000), Decadal changes along an Indian Ocean section at $32^{\circ} \mathrm{S}$ and their interpretation, J. Phys. Oceanogr., 30(6), 1207-1222, doi:10.1175/1520-0485(2000)030<1207: DCAAIO $>2.0 . \mathrm{CO} ; 2$. 
Bryden, H. L., E. L. McDonagh, and B. A. King (2003), Changes in ocean water mass properties: Oscillations or trends?, Science, 300, 2086-2088, doi:10.1126/science. 1083980 .

Cai, W. J., P. H. Whetton, and D. J. Karoly (2003), The response of the Antarctic Oscillation to increasing and stabilized atmospheric $\mathrm{CO}_{2}$, J. Clim., 16, 1525-1538.

Cai, W. J., G. Shi, T. Cowan, D. Bi, and J. Ribbe (2005), The response of the Southern Annular Mode, the East Australian Current, and the southern mid-latitude ocean circulation to global warming, Geophys. Res. Lett., 32, L23706, doi:10.1029/2005GL024701.

Curry, R., B. Dickson, and I. Yashayaev (2003), A change in the freshwater balance of the Atlantic Ocean over the past four decades, Nature, 426, 826-829, doi:10.1038/nature02206.

Gille, S. T. (2002), Warming of the Southern Ocean since 1950s, Science, 295, 1275-1277, doi:10.1126/science.1065863.

Hanawa, K., and L. D. Talley (2001), Mode waters, in Ocean Circulation and Climaten: Observing and Modelling the Global Ocean, Int Geophys. Ser., vol. 77, edited by G. Siedler, J. Church, and J. Gould, pp. 373-386, Academic, San Diego, Calif.

Hughes, C. W., and E. R. Ash (2001), Eddy forcing of the mean flow in the Southern Ocean, J. Geophys. Res., 106(C2), 2713-2722.

Johnson, G. C., and A. H. Orsi (1997), Southwest Pacific Ocean water mass changes between 1968/69 and 1990/91, J. Clim., 10, 306-316, doi:10.1175/1520-0442(1997)010<0306:SPOWMC $>2.0 . C O ; 2$.

Le Traon, P., F. Nadal, and N. Ducet (1998), An improved mapping method of multisatellite altimeter data, J. Atmos. Oceanic Technol., 15, 522-534, doi:10.1175/1520-0426(1998)015<0522:AIMMOM>2.0.CO;2.

McCartney, M. S. (1977), Subantarctic Mode Water, in A Voyage of Discovery, Deep-Sea Research George Deacon 70th Anniversary Volume, edited by M. Angel, pp. 103-119, Pergamon, New York.

McCartney, M. S. (1982), The subtropical recirculation of mode waters, J. Mar. Res., 40, suppl., 427-464.

Meredith, M. P., and A. M. Hogg (2006), Circumpolar response of Southern Ocean eddy activity to a change in the Southern Annular Mode, Geophys. Res. Lett., 33, L16608, doi:10.1029/2006GL026499.

Metzl, N., B. Tillbrook, and A. Poisson (1999), The annual $f \mathrm{CO}_{2}$ cycle and the air-sea $\mathrm{CO}_{2}$ flux in the sub-Antarctic Ocean, Tellus, Ser. B 51, 849-861, doi:10.1034/j.1600-0889.1999.t01-3-00008.x.

Morrow, R., A. Brut, and A. Chaigneau (2003), Seasonal and interannual variations of the upper ocean energetics between Tasmania and Antarctica, Deep Sea Res., Part I, 50, 339-356, doi:10.1016/S0967-0637(03) 00015-3

Morrow, R., J. R. Donguy, A. Chaigneau, and S. R. Rintoul (2004), Coldcore anomalies at the Subantarctic Front, south of Tasmania, Deep Sea Res., Part I, 51, 1417-1440.

Morrow, R., G. Valledean, and J.-B. Salleé (2008), Observed subsurface signature of Southern Ocean sea level rise, Prog. Oceanogr., 77(4), 351-366, doi:10.1016/j.pocean.2007.03.002.

Naveira-Garabato, A. C., L. Jullion, D. P. Stevens, K. J. Heywood, and B. A. King (2009), Variability of Subantarctic Mode Water and Antarctic Intermediate Water in Drake Passage during the late 20th and early $21 \mathrm{st}$ centuries, J. Clim., 22 doi:10.1175/2009JCLI2621.1.

Olbers, D., V. Gouretski, G. Seiß, and J. Schröter (1992), Hydrographic Atlas of the Southern Ocean, 17 pp. +82 plates, Alfred Wegener Inst. for Polar and Mar. Res., Bremerhaven, Germany.

Onogi, K., et al. (2007), The JRA-25 reanalysis, J. Meteorol. Soc. Jpn., 85, 369-432, doi:10.2151/jmsj.85.369.

Orsi, A. H., T. Withworth III, and W. D. Nowlin Jr. (1995), On the meridional extent and fronts of the Antarctic Circumpolar Current, Deep Sea Res., Part I, 42, 641-673, doi:10.1016/0967-0637(95)00021-W.

Phillips, H. E., and S. R. Rintoul (2000), Eddy variability and energetics from direct current measurements in the Antarctic Circumpolar Current south of Australia, J. Phys. Oceanogr., 30(12), 3050-3076, doi:10.1175/15200485(2000)030<3050:EVAEFD>2.0.CO;2.

Provost, C., C. E. Scoffier, K. Maamaatuaiahutapu, A. Kartavtseff, and V. Garcon (1999), Subtropical Mode Waters in the South Atlantic Ocean, J. Geophys. Res., 104(C9), 21,033-21,049, doi:10.1029/1999JC900049.

Qiu, B., S. Chen, K. A. Donohue, D. R. Watts, H. Mitsudere, N. G. Hogg, and S. R. Jayne (2006), Observations of the Subtropical Mode Water evolution from the Kuroshio Extension system study, J. Phys. Oceanogr., 36(3), 457-471, doi:10.1175/JPO2849.1.

Ridgway, K. R. (2007a), Seasonal circulation around Tasmania: An interface between eastern and western boundary dynamics, J. Geophys. Res., 112, C10016, doi:10.1029/2006JC003898.

Ridgway, K. R. (2007b), Long-term trend and decadal variability of the southward penetration of the East Australian Current, Geophys. Res. Lett., 34, L13613, doi:10.1029/2007GL030393.

Rintoul, S. R., and J. L. Bullister (1999), A late winter hydrographic section from Tasmania to Antarctica, Deep Sea Res., Part I, 46, 1417-1454, doi:10.1016/S0967-0637(99)00013-8

Rintoul, S. R., and M. H. England (2002), Ekman transport dominates local air-sea fluxes in driving variability of Subantarctic Mode Water, J. Phys. Oceanogr., 32(5), 1308-1321, doi:10.1175/1520-0485(2002)032<1308: ETDLAS $>2.0$.CO;2.

Rintoul, S. R., S. Sokolov, and J. A. Church (2002), A 6 year record of baroclinic transport variability of the Antarctic Circumpolar Current at $140^{\circ} \mathrm{E}$ derived from expendable bathythermograph and altimeter measurements, J. Geophys. Res., 107(C10), 3155, doi:10.1029/2001JC000787.

Sabine, C., et al. (2004), The oceanic sink for anthropogenic $\mathrm{CO}_{2}$, Science, 305, 367-371, doi:10.1126/science. 1097403 .

Sallée, J. B., R. Morrow, and K. Speer (2008), Eddy heat diffusion and Subantarctic Mode Water formation, Geophys. Res. Lett., 35, L05607, doi:10.1029/2007GL032827.

Sarmiento, J. L., N. Gruber, M. A. Brzezinski, and J. P. Dunne (2004), High-latitude controls of thermocline nutrients and low latitude biological productivity, Nature, 427, 56-60, doi:10.1038/nature02127.

Sloyan, B., and S. R. Rintoul (2001), Circulation, renewal and modification of Antarctic Mode and Intermediate Water, J. Phys. Oceanogr., 31(4), 1005-1030, doi:10.1175/1520-0485(2001)031<1005:CRAMOA>2.0. $\mathrm{CO} ; 2$.

Sokolov, S., and S. R. Rintoul (2000), Circulation and water masses of the southwest Pacific: WOCE section P11, Papua New Guinea to Tasmania, J. Mar. Res., 58, 223-268, doi:10.1357/002224000321511151.

Sokolov, S., and S. R. Rintoul (2002), Structure of Southern Ocean fronts at $140^{\circ} \mathrm{E}, J$. Mar. Syst., 37, 151-184, doi:10.1016/S0924-7963(02) 00200-2.

Sokolov, S., and S. R. Rintoul (2007), Multiple jets of the Antarctic Circumpolar Current south of Australia, J. Phys. Oceanogr., 37(5), 1394-1412, doi:10.1175/JPO3111.1.

Speer, K., S. R. Rintoul, and B. Sloyan (2000), The diabatic Deacon cell, J. Phys. Oceanogr., 30(12), 3212-3222, doi:10.1175/1520-0485 (2000) $030<3212$ :TDDC $>2.0 . \mathrm{CO} ; 2$.

Stark, S., R. A. Wood, and H. T. Banks (2006), Reevaluating the causes of observed changes in Indian Ocean water masses, J. Clim., 19, 4075-4086, doi:10.1175/JCLI3845.1.

Thompson, D. W. J., and S. Solomon (2002), Interpretation of recent Southern Hemisphere climate change, Science, 296, 895-899, doi:10.1126/science. 1069270 .

Wolff, J. O., E. Maier-Reimer, and D. Olbers (1991), Wind-driven flow over topography in a zonal $\beta$-plane channel: A quasi-geostrophic model of the Antarctic Circumpolar Current, J. Phys. Oceanogr., 21(2), 236-264, doi:10.1175/1520-0485(1991)021<0236:WDFOTI >2.0.CO;2.

Wong, A. P. S., N. L. Bindoff, and J. A. Church (1999), Large-scale freshening of intermediate waters in the Pacific and Indian oceans, Nature, 400, 440-443, doi:10.1038/22733.

Wong, A. P. S., N. L. Bindoff, and J. A. Church (2001), Freshwater and heat changes in the North and South Pacific oceans between the 1960s and 1985-94, J. Clim., 14, 1613-1633, doi:10.1175/1520-0442(2001) 014<1613:FAHCIT>2.0.CO;2.

L. Herraiz-Borreguero, Institute of Antarctic and Southern Ocean Studies, University of Tasmania, Hobart, Tas 7000, Australia. (lherraiz@ utas.edu.au)

S. R. Rintoul, Centre for Australian Weather and Climate Research, GPO Box 1538, Castray Esplanade, Hobart, Tas 7000, Australia. 